\title{
BUMBA MEU BOI, BOI-BUMBÁ: a inventividade das tradições populares
}

\section{THE OX DANCE AND THE INVENTIVENESS OF POPULAR TRADITIONS}

\author{
Maria Laura Viveiros de Castro Cavalcanti
}

\begin{abstract}
Resumo
No contexto do ensaio "As danças dramáticas no Brasil”, de Mário de Andrade, publicado em 1944, o Bumba Meu Boi ganhou notoriedade erguido a um só tempo a símbolo do encantamento das expressões populares e da possibilidade de sua deterioração e perda. As ideias ambivalentes expressas por Andrade a seu respeito influenciaram de modo marcante os estudos subsequentes. Ao discutir criticamente essa influência nos estudos posteriores, indicamos a circularidade cultural existente entre os estudos das expressões populares e a própria dinâmica viva de tais expressões. Isso feito, a vigorosa contemporaneidade do Boi-Bumbá de Parintins, Amazonas, é apresentada de modo a realçar um dos aspectos analíticos das formulações andradianas que permanece instigante para a pesquisa contemporânea: seu interesse pelas dimensões estéticas e performáticas das expressões populares. Visto por esse ângulo, o Bumbá de Parintins afirma a surpreendente capacidade inventiva das tradições populares.
\end{abstract}

Palavras-chave: Danças dramáticas. Mário de Andrade. Bumbá de Parintins. Formas Expressivas.

\section{Abstract}

In the context of Mário de Andrade’s essay "Dramatic Dances in Brazil," published in 1944, Bumba meu boi [Dance my ox or Ox Dance] gained notoriety both as a symbol of the enchantment of popular expressions and of the possibility of their deterioration and loss. The ambivalent ideas expressed by Andrade about the "bumba" have markedly influenced subsequent approaches to this subject and are briefly examined here. In critically discussing their influence on later studies, we indicate the cultural circularity existing between these studies of popular expressions and the very dynamic dynamics of such expressions. Once this is done, the vigorous contemporaneity of Boi Bumbá de Parintins, Amazonas is presented and with it we turn back and retain the analytical aspect of the Andrade's formulations that accentuate the aesthetic and performative dimensions of popular expressions. The surprising inventiveness of popular traditions is therefore affirmed.

Key words: Dramatic Dances. Mario de Andrade. Parintins Ox Dance. Expressive cultural forms.

\section{Introdução}

O festival dos Bois-Bumbás acontece anualmente nas três últimas noites do último fim de semana de junho na cidade de Parintins, Amazonas, localizada na ponta de uma das ilhas do arquipélago das Tupinambaranas no Médio Rio Amazonas, bem próxima à fronteira com o Pará. Tão logo comecei a pesquisá-lo, nos idos de $1996^{1}$, pude comprovar a impressionante

\footnotetext{
* Professora Titular do Programa de Pós-Graduação em Sociologia \& Antropologia do Instituto de Filosofia e Ciências Sociais da Universidade Federal do Rio de Janeiro. Pesquisadora de festas e rituais contemporâneos e da história da antropologia no Brasil. E-mail: cavalcanti.laura@gmail.com

1 Acompanho, de perto e de longe, o Bumbá de Parintins desde 1996, tendo realizado pesquisa de campo nos períodos festivos de 1996 e 1997, 2000, 2004 e 2010. Esse material de pesquisa vem sendo sistematizado sob diferentes ângulos ao longo dos anos (CAVALCANTI 2000, 2002, 2006, 2011, 2012a, 2018). Para uma etnografia detalhada do festival e a história de sua evolução, ver Cavalcanti (2000). A análise da visualidade espetacular das performances na arena pode ser conferida em Cavalcanti (2015), e a dimensão mítica do Bumbá, em Cavalcanti (2006).
} 
visualidade espetacular e a dimensão massiva de suas apresentações na arena festiva que haviam atraído meu interesse de pesquisadora de outra festa espetacular, o desfile das escolas de samba do Rio de Janeiro (CAVALCANTI, 2006). O “Bumbódromo”, construído em 1988 para abrigar o confronto festivo entre os Bois Caprichoso e Garantido, abriga 16 mil e quinhentos assentos e a cada noite os Bois se apresentam com 3.500 brincantes com renovados figurinos e alegorias. No entanto, conforme minha compreensão se aprofundava, esse festival contemporâneo e espetacular de Parintins, inscrito no ciclo festivo junino característico do norte do país configurou-se claramente como uma variante ímpar do tradicional folguedo do boi. ${ }^{2}$

Essa percepção me remetia inevitavelmente a toda tradição dos estudos de folclore no país, pois, esse folguedo, para usarmos uma designação bem característica dos estudiosos de folclore, foi registrado no Norte e no Nordeste desde a primeira metade do século XIX (SALLES, 1970; LOPES GAMA, 1996). Vi-me então às voltas com o estudo mais detalhado dos escritos dos folcloristas relativos ao folguedo, e logo embrenhada na leitura do ensaio "As danças dramáticas do Brasil" (doravante DD) de Mário de Andrade, publicado no volume póstumo, organizado por Alvarenga, Danças Dramáticas Brasileiras (DDB) (ANDRADE,1982). Esse ensaio evidencia a importância de que se revestia para Mário de Andrade o Bumba meu boi, que se destacava entre as danças dramáticas estudadas por ele ${ }^{3}$. Nele evidencia-se também uma certa visão do folguedo que ressoa fortemente em muitos estudos posteriores. Retomarei aqui brevemente alguns pontos estabelecidos acerca da centralidade do Bumba meu boi na obra de Mário de Andrade. E, como um Boi sempre chama o outro para brincar, o Bumbá de Parintins atenderá aqui ao chamado de Mário de Andrade ${ }^{4}$. Ressurgirá das cinzas da desalentada sentença de morte proferida por Andrade para as danças dramáticas ao final de seu texto e, ao fazê-lo, o seu vigor nos trará também a surpreendente atualidade de algumas das ideias do autor e a afirmação da capacidade inventiva da cultura popular.

\footnotetext{
2 Folguedo do Boi (termo preferido pelos folcloristas), brincadeira do Boi (termo preferido pelos brincantes), Bumba Meu Boi (termo nordestino), Boi-Bumbá (termo nortista), ou simplesmente Boi (também muito usado em Parintins) são termos utilizados aqui como equivalentes para designar a performance festiva que, de formas muito variadas, agrega um grupo humano em torno do artefato de um boi que dança, animado desde seu interior por um brincante.

3 Ver "Cultura popular e sensibilidade romântica: as Danças Dramáticas de Mário de Andrade", em Cavalcanti, 2012b.

4 Vale observar que, em 1 de junho de 1927, Mário de Andrade esteve em Parintins, onde os dois bois que hoje brincam já existiam desde 1912/1913, mas ele nem os viu nem os mencionou. Chegou de tarde numa breve pausa de viagem. Em 29 de maio, estava em "pleno Amazonas", na foz do Tapajós, tendo parado em Itamarati no dia seguinte. Depois disso, a comitiva desceu em Parintins, onde encontrou um "prefeito bem-falante". Mário de Andrade transcreve o "Apostolado da oração" encontrado na visita a uma igreja local que estabelecia que seus fiéis: "Renunciariam totalmente às danças; 2) renunciam a máscaras e fantasias; 3 ) não tomam parte em festas particulares etc. [...]. O grupo seguiu para Itacoatiara, a caminho de Manaus. Na volta, em 23 de julho, o diário registra "Parintins pela madrugada, vista em sonhos" (ANDRADE, 1976, p. 76). Parintins era certamente uma cidade festiva!
} 


\section{O Boi em Mário de Andrade}

Em seus trabalhos, Moraes $(1978,1992)$ destacou a importância da noção de folclore na arquitetura do nacionalismo cultural andradiano. Para Mário de Andrade, as expressões folclóricas, consideradas tradicionais, abrigavam os requisitos de autenticidade, originalidade e universalidade que deveriam nortear a produção artística erudita nacional. Por essa razão, para conhecê-las e registrá-las, Mário de Andrade buscou o contato com a "gente do povo" e, dentro do Modernismo brasileiro, pode ser visto como o representante de uma "via de pesquisa, no sentido quase universitário da palavra" (MORAES, 1978, p. 93).

Lopez $(1972,2002)$, por sua vez, ao examinar a presença do Boi como símbolo na poesia do autor, observou a posição especial ocupada pelo Bumba Meu Boi em seus estudos de folclore. Também em seu magistral ensaio, Mello e Souza (1979) defendeu o papel central do Bumba Meu Boi na criação de Macunaíma (ANDRADE, 1988). Ao revelar a presença das formas europeias da suíte e da variação na música e na dança populares, o Bumba seria também "o bailado popular que melhor representava a nacionalidade" (MELLO E SOUZA, op. cit. p. 17). Porém, em sua interpretação, Mello e Souza enfatizou muito acertadamente a dimensão trágica de Macunaíma.

José Guilherme Merquior (1981, p. 17), em sua arguta resenha do livro de Mello e Souza, apreendeu-o como "um romance arturiano que tomou uma tremenda injeção de ambivalência”. Afinal, nos lembra ele, não se trata apenas do herói que perde e recobra repetidamente seu amuleto mágico. Trata-se também, e sobretudo, do anti-herói que termina, finalmente, perdendo seu amuleto por conta de uma escolha funesta. A interpretação de Mello e Souza é iluminadora, ao reconhecer a "fissura profunda que fere todos os setores da reflexão de MA" (MELLO E SOUZA, op. cit. p. 60) e ao enxergar a ambivalência e o pessimismo de Macunaíma. O Bumba Meu Boi é claramente apreendido como "referência, tinha intenção ideológica e se ligava ao complexo sistema de sinais com que o escritor se habituara a pensar não só a realidade do seu país, mas a sua realidade pessoal" (op. cit. p. 17).

Nesse debate, o meu ponto é o de que a eleição do Bumba como símbolo do nacionalismo cultural proposto por Mário de Andrade não se fez sem consequências complicadas para a compreensão do folguedo em seu próprio circuito cultural muito heterogêneo e cambiante. Uma sombra a um só tempo ufanista e pessimista como que obscureceu o olhar mais etnográfico e antropológico sobre o folguedo propriamente dito. Busquei compreender de mais perto esse lugar de "melhor representante da nacionalidade" atribuído ao Bumba Meu Boi por Mário de Andrade de modo a podermos integrar mais plenamente a ambivalência de suas avaliações à visão construída sobre o próprio folguedo. Com isso, como buscarei demonstrar com o exame do Bumbá de Parintins, extraímos consequências relevante para a análise contemporânea. 
No ensaio "As danças dramáticas do Brasil", que abre os três tomos de Danças dramáticas do Brasil de Mário de Andrade (1982), o autor propôs o conceito de danças dramáticas para realçar a unidade de folguedos populares até então considerados separadamente - em especial aqueles genericamente designados na classificação erudita, como Pastoris, Cheganças, Reisados. As melodias e coreografias que completam e compõem o conjunto dos volumes, por sua vez, foram coletadas em sua maioria durante a viagem do autor ao Nordeste, realizada entre 27 de novembro de 1928 e 5 de fevereiro de $1929^{5}$.

O ensaio foi publicado por Mário de Andrade em 1944 no 6º Boletim Latino-Americano de Música. O Instituto de Estudos Brasileiros (IEB), da Universidade de São Paulo, dispõe das versões anteriores àquela publicada. Em pesquisa documental que realizei, pude verificar que o corpo do texto já estava delineado na primeira versão datada de 1934, de 27 páginas ${ }^{6}$, que contém na última página a anotação a lápis feita pelo autor: "decadência atual das d. dramáticas". A versão seguinte desenvolveu então o tema da decadência. Ainda no mesmo ano de 1934, essa segunda versão foi revisada, gerando uma terceira versão e, logo depois, uma "terceira versão corrigida na leitura", que traz muitas anotações e acréscimos em suas margens. A confecção do texto se interrompeu então e seria retomada apenas dez anos mais tarde para a versão finalmente publicada em 1944.

O empenho das sucessivas revisões realizadas em 1934 bem indica o empenho do autor em seus estudos de folclore mais sistemáticos e aprofundados, e o intervalo de dez anos até a publicação da versão definitiva parece sugerir também alguma hesitação e incerteza com relação a seu resultado final. $\mathrm{O}$ acréscimo de muitas notas, de bibliografia, de trechos inéditos ou já redigidos por ele para outros propósitos torna (como é usual, por sinal, em sua obra folclórica) seu texto curiosamente assemelhado ao próprio processo de composição das danças dramáticas nele descrito: inchado de elementos que recheiam o argumento central num intrigante processo de "justaposição discricionária". ${ }^{7}$

O ensaio sobre as danças dramáticas é, em suma, um texto de difícil leitura que emerge, entretanto, como central para a caracterização de Mário de Andrade como um folclorista que compartilhava os ideais de rigor e cientificidade das nascentes ciências sociais de então, mas que, ao mesmo tempo, não se sentia totalmente à vontade nesse manejo ${ }^{8}$. A voz do artista, com

5 Os escritos das duas viagens de Andrade foram reunidos e comentados por Telê Porto Ancona Lopez no livro $O$ Turista Aprendiz (ANDRADE, 1976). Como nos esclarece Lopez, a narrativa da segunda viagem se compõe das 70 crônicas escritas durante a viagem para o jornal Diário Nacional e publicadas como uma série também denominada "O turista aprendiz", entre 14 de dezembro e 29 de março de 1929 (LOPEZ In: ANDRADE, 1976, p. 41).

6 Esta versão termina no trecho correspondente ao da penúltima página da versão publicada com a palavra "Rio Grande do Norte" (ANDRADE, 1982, p. 69).

7 No ensaio Música de feitiçaria no Brasil (ANDRADE, 1983), vertido para o inglês por Peter Fry, que está disponível no volume 14, número 1, da revista Vibrant on-line, esse mesmo caráter de bricolagem se evidencia. Ver a respeito Maria Laura Cavalcanti e Peter Fry, 2017.

8 Sobre o Curso de Etnografia oferecido por Dina Dreyfus Lévi-Strauss em 1937 por iniciativa de Mário de Andrade, então à frente da Secretaria Municipal de Cultura de São Paulo, ver Valentini (2013) e Soares (1983). 
sua fina ironia e humor, sempre acaba por se juntar à narrativa mais douta, e creio que devemos a ela a expressão de certos interesses e visões que só seriam incorporados às preocupações acadêmicas bem mais tarde 9 .

No plano estético, a unidade das danças dramáticas repousaria, como já mencionado, na forma rapsódica de composição comum a todas elas, porém especialmente nítida no Bumba Meu Boi. A ideia de suíte, que indica composições musicais de natureza também coreográfica, alarga-se na conceituação do autor, abrangendo a dimensão dramatizada do folguedo. As danças dramáticas se dividiriam em duas partes bem distintas, o cortejo (com peças que permitem a mobilidade) e uma parte propriamente dramática, com a representação de um entrecho que exigiria a fixação do grupo em palco, tablado, praça, à frente da casa ou da igreja (ANDRADE, 1982, p. 57). Esse entrecho dramático, muitas vezes também denominado como "núcleo básico", e no qual se apresentaria o tema central da dança, ocupa lugar estratégico na conceituação de Mário de Andrade. Pois, a inteireza dessas danças dramáticas depende da maneira como suas diferentes partes se articulam com o tema central exposto justamente no entrecho dramatizado. Esse tema funcionaria, então, como um "princípio de agregação" a presidir e ordenar a seriação e a justaposição características das diversas peças musicais e dramáticas que compõem esses bailados.

Ao longo do ensaio, se seguimos esse fio de Ariadne - a forma como se articulam as diferentes partes de uma dança dramática com a exposição no entrecho de seu tema central -, podemos apreender a clara oscilação do autor entre uma visão mais integrada e outra mais fragmentária das danças dramáticas. Quando essa articulação é vista de forma mais integrada, reconhecemos no texto a busca de "um conteúdo fixo nacionalizante", que tanto norteou a atuação cultural de Mário de Andrade. Quando essa articulação é percebida como mais fragmentária, deparamo-nos com o desalento diante do que é percebido como uma inexorável perda das tradições populares mais autênticas.

No que tange à visão mais integrada das danças, um trecho da primeira versão da redação das DD, depois retirado, permite perceber claramente a valorização da unidade intelectual e estética propiciada pelo "entrecho dramático" em um Boi-Bumbá:

Tive ocasião de assistir a um boi-bumbá - nome amazônico do Bumba-meu-boi, na cidadinha [sic.] de Humaitá no Madeira. Colhi mesmo dela várias cantigas. Era uma peça admiravelmente unida, em que todos os episódios se juntavam ao núcleo de mor-

\footnotetext{
9 Vale a pena ler o último relato da viagem ao Nordeste, o segundo diário de O Turista Aprendiz (1976, p. 320), feito na Paraíba. Essa viagem, como nos esclareceu Lopez (1976), tem relação orgânica com o projeto de estudo que resultou no ensaio das DD. O interesse de Mário de Andrade pela música é evidente em sua obra e já foi bem ressaltado em sua fortuna crítica. Em texto póstumo, Travassos (2014) sugeriu o quanto a leitura do autor pelo viés dos estudos da performance e rituais - que tanto interessam à antropologia e à etnomusicologia contemporâneas - pode ser estimulante. Nas DD, entretanto, o autor, além de chamar a atenção para a dramatização na cultura popular, evidencia também seu grande interesse pela dança. Essa forma expressiva, na situação presencial e sinestésica de uma performance festiva, comovia particularmente o autor. A associação entre música, dança e drama encontrada por Mário de Andrade nas formas populares parece sugerir a solução de um dos problemas críticos de sua busca estética: a integração plena entre arte e vida.
} 
te e ressurreição do boi, sempre em referência com ele. Era legitimamente o reisado do bumba-meu-boi a que apenas tinham se ajuntado episódios desenvolvidos do próprio assunto (ANDRADE, 1934a, p. 19).

$\mathrm{Na}$ visão mais fragmentária, contudo, essa forma de composição popular rechearia o "núcleo básico" com temas apostos oriundos de outras fontes de inspiração que nele "se grudam" e, que por vezes, "não têm ligação nenhuma com o núcleo" (Andrade, 1982, p. 53-54).

No conjunto das danças ${ }^{10}$, sobressaem-se os Reisados. Eles tematizam "sempre o assunto de imemorial significação mágica em que se dá a morte e ressurreição do bicho ou planta" (op. cit., p. 39). Entre os 24 Reisados compilados em seus estudos, Mário de Andrade destacou o Bumba Meu Boi, o Reisado expansionista que tendia a aglutinar todos os demais, tendo "permanecido muito vivo até agora" (p. 50). O Bumba seria "a mais exemplar" (p. 54), mas também, lembremos, "a mais complexa, estranha, original de todas as nossas danças dramáticas" (ANDRADE, 1982, p. 53). Para Mário de Andrade, embora o sentido mais pleno do mito de morte e ressurreição do bicho precioso já se tivesse perdido, ele perduraria ainda entre o povo como sobrevivência de uma camada arcaica de humanidade ${ }^{11}$. Por essa razão, o Bumba emerge na obra de Mário de Andrade como o elo de uma brasilidade com a dimensão universal das culturas humanas. Ao final do périplo investigativo, entretanto, um triste destino foi anunciado pelo autor para as danças que tanto o fascinavam: "Da maneira como as coisas vão indo, a sentença é de morte" (op. cit., p. 70).

\section{Reverberações}

As formulações de Mário de Andrade reverberaram em muitos trabalhos posteriores (MEYER, 1991; PEREIRA DE QUEIROZ, 1967; BORBA FILHO, 1966) e foram aos poucos criando um curioso efeito de neblina em torno da compreensão da brincadeira do Boi ${ }^{12}$.

Como vimos, na visão mais integrada do Bumba Meu Boi proposta por Mário de Andrade, ao apresentar o tema da morte e ressurreição do bicho precioso, o "entrecho dramático" ou "núcleo básico" forneceria um princípio de unidade intelectual e estética ao bailado seriado. Vale enfatizar que muitos Bumbas efetivamente encontrados por Mário de Andrade não apresentavam essa unidade e revelavam um modo de ser muito fragmentário e desordenado. Contudo, é a visão integrada, assimilada aos anseios do nacionalismo cultural, a que prevaleceu na bibliografia de estudiosos subsequentes. Com isso, a ideia de um "entrecho dramático central" foi aos poucos ganhando um conteúdo mais definido.

10 Pastoris e Cheganças, de origem ibérica a seu ver, também integram o conjunto das danças consideradas. Elas tematizariam mais simplesmente do que os Reisados o tema elementar de qualquer drama: a luta de um bem contra um mal, o perigo e a salvação (op. cit., p. 25).

11 O conceito de sobrevivência, formulado por Edward B. Tylor (1871) foi muito importante nos estudos antropológicos evolucionistas de fins do século XIX lidos por Mário de Andrade.

12 Abordei esse problema detidamente em “Tempo e narrativa nos folguedos do boi” (CAVALCANTI, 2102c). 
Ela parece ter se combinado com a ideia anterior vigente na bibliografia dos estudos de folclore de um "auto" popular - termo que designa uma forma tradicional de teatro popular alusiva às formas alegóricas do teatro medieval trazidas pelos jesuítas para as terras brasileiras ${ }^{13}$. Supõe-se, então, que, baseados nesse auto, que supriria como que um roteiro para a brincadeira, os grupos de Boi encenariam em suas apresentações uma trama baseada na lenda da morte e ressurreição de precioso boi. O fato notável é que tudo isso emerge quase sempre associado à ideia de uma perda inexorável em curso nas expressões do folclore e da cultura popular, pois parece nunca ter sido fácil encontrar a forma esperada do tal "auto".

A visão de Ascenso Ferreira (1944, p. 52), colaborador de Mário de Andrade, elaborada na esteira de suas formulações, bem sintetiza esse deslocamento. Para ele, o Bumba Meu Boi era "o mais nebuloso dos bailados do Nordeste", pois, tendo sido outrora um auto, "do enredo desse auto é que se perdeu indiscutivelmente o roteiro".

Não importa que Artur Azevedo comentasse já em 1906:

É mesmo provável que o bumba meu boi, na sua forma primitiva, fosse um auto composto, com todas as regras do gênero, por algum poeta do povo [...]. Hoje é simples folguedo, sem significação alguma, exibindo vários personagens cujas funções não estão logicamente determinadas (AZEVEDO, 1906, p.5).

Como sabemos, a partir do final dos anos 1940, os ideais de registro, divulgação e valorização do folclore, foram acolhidos pelo Movimento Folclórico Brasileiro (MFB) que culminou com a criação da Campanha de Defesa do Folclore Brasileiro (CDFB) em 1958, e sua posterior transformação em Instituto Nacional do Folclore (INF), em 1976 (VILHENA, 1997 ${ }^{14}$. Articulado em torno de Renato Almeida ${ }^{15}$, o movimento alcançou penetração capilar no território nacional por meio da atuação de comissões locais em muitos estados, e com a promoção de diversas semanas e congressos em diferentes capitais brasileiras.

Importa observar que começamos a encontrar conteúdos mais definidos para o "auto" supostamente encenado pelo Bumba Meu Boi na literatura disponível apenas no contexto dos estudos fomentados pelo Movimento Folclórico Brasileiro. Resumo livremente um exemplo de narrativa do auto produzido nesse contexto: era uma vez um boi precioso, o touro predileto de um rico fazendeiro, dado de presente a sua filha, ou em algumas versões a sua esposa. $\mathrm{O}$ boi foi entregue aos cuidados de um leal vaqueiro, Pai Francisco, ou "Nêgo" Chico. Mas a mulher de Pai Francisco estava grávida e desejou comer a língua desse precioso boi. Premido entre o desejo de sua mulher e a lealdade a seu patrão, Francisco termina por matar o boi. Essa 'traição' ao amo -

13 Nas DD, Mário de Andrade chega a dizer: “(...) minha sensação é que os autos tiveram pouquíssima influência, se alguma tiveram, na formação direta das danças dramáticas” (ANDRADE, op. cit, p. 30).

14 Em 2003, o INF passou a integrar o Instituto do Patrimônio Histórico e Artístico Nacional (IPHAN) como Centro Nacional de Folclore e Cultura Popular.

15 Para a relação entre Renato Almeida e Mario de Andrade, ver Martins (2009). 
que é, ao mesmo tempo, 'lealdade’ à esposa e a sua prole - provoca um terrível impasse quando descoberta. $O$ fazendeiro suspenderá a punição ao vaqueiro se este ressuscitar o boi! Um médico e um padre tentam a ressurreição do bicho, finalmente obtida por um pajé. Então, nos dizem essas narrativas, seguindo-se ao perdão, "o grupo todo celebra em festa"16.

Apresentei em outro trabalho (CAVALCANTI, 2012c) a hipótese de que essas narrativas colhidas pelos estudiosos de folclore, sobretudo entre os anos 1940-1970, resultam da transposição para a forma escrita de relatos orais de mitos de origem vigentes entre os brincantes de boi nesse mesmo período. Mitos de origem no sentido estruturalista: narrativas variadas que instauram o tempo extraordinário do presente festivo e estabelecem a continuidade simbólica entre presente e passado (LÉVI-STRAUSS, 1976). Os relatos relativos do "auto" são narrativas ficcionais profundamente reveladoras de valores sociais contemporâneos e, em sua dramatização simbólica, muito expressivas de conflitos e lealdades entre grupos sociais distintos que compuseram a formação da sociedade brasileira. Afinal, nelas vemos geralmente simbolizado o famoso triângulo racial (o negro, o índio e o branco) - hierárquico e desigual - que, na visão de Roberto DaMatta (1987), instituiria um dos mitos basilares da dinâmica cultural brasileira. São, entretanto, narrativas orais acerca de uma origem mítica, que foram tomadas a meu ver equivocadamente como uma espécie de enredo fixo situado na suposta origem histórica da brincadeira do boi, e a ser nela necessariamente encenado. Nada mais natural, portanto, do que serem dificilmente encontradas na forma em que são procuradas ${ }^{17}$.

Porém, qual a relação disso tudo com o Bumbá de Parintins, hoje? As tradições culturais populares, mais do que "inventadas" (HOBSBAWN, 2006), revelam-se, como veremos nesse caso, sobretudo como profundamente "inventivas", isto é, modalidades culturais singulares em meio aos processos de mudança e continuidade socioculturais (SAHLINS, 2004) ${ }^{18}$.

\section{O Bumbá de Parintins, Amazonas}

Vale dizer que o Bumbá é não só a culminância do Festival Folclórico de Parintins, como seus organizadores e brincantes reivindicam para si o lugar de "uma das mais expressivas

16 Analisei em detalhes 13 variantes dessa narrativa mítica em Cavalcanti, 2006. A narrativa de referência para essa análise é a de Bordallo da Silva (1981), aqui reproduzida livremente.

17 Para um eloquente depoimento dessa dificuldade e o consequente deslocamento da pesquisa que descortinou todo um desconhecido conjunto de performances e práticas narrativas entre os brincantes de boi maranhenses, ver Carvalho (2011). A encenação de um "auto" é recorrente sobretudo entre os grupos parafolclóricos que reencenam e adaptam para seus próprios propósitos as expressões culturais populares. Por vezes, pode também resultar em uma espécie de "metafolclore", pois um grupo brincante encena-o por supor que isso é o que se espera dele, seja por pressão intelectual ou das políticas culturais em curso.

18 O conceito de "invenção das tradições", proposto por Hobsbawn (op. cit.), enfatiza em perspectiva histórica de cunho marxista o aspecto ideológico e politicamente consciente da atuação dos grupos culturais. Embora útil e válido para certos contextos específicos, ele está bastante distante de conceitos mais antropológicos de cultura que insistem em considerar a dimensão total dos fatos e processos sociais, incluindo neles também a dimensão inconsciente e produtora de efeitos não necessariamente almejados pelos atores sociais imersos nos processos culturais. Para uma boa explanação desse debate, ver Gonçalves, 2010. 
manifestações folclóricas do país" (Caprichoso. Centenário de uma paixão. Roteiro de apresentação de 2013, p. 19).

As múltiplas narrativas de origem que acompanham de modo muito variado as diversas formas da brincadeira do boi no Brasil estão também presentes de modo singular em Parintins. Elas são um aspecto estratégico na valorização dos Bumbás de sua ligação com o "folclore tradicional". Nessas narrativas, como vimos, o boi é bicho mítico que morre e ressuscita. No Bumbá, podemos vincular aos atributos desse bicho mítico as características de força, resistência e potência expressas tanto nos antigos e violentos enfrentamentos de rua (os dois Bumbás surgiram em Parintins na segunda década do século XX) como na acentuada rivalidade que organiza a festa atual (a criação do Festival Folclórico data de 1965) ${ }^{19}$. Essa potência se afirma também na masculinidade dos agressivos desafios entoados na arena nas noites festivas pelos Amos do Boi - os cantores e compositores que encarnam esse personagem nas performances e que chamam com seu berrante o boi-artefato para brincar na arena nas três noites em que os dois Bumbás se revezam em suas apresentações. Ao bicho mítico liga-se também a própria agremiação como um todo - o Boi Caprichoso ou Garantido, as duas agremiações rivais, simbolizadas respectivamente pelas cores azul e preto e vermelho e branco. E esse grupo de brincantes é quem deseja afinal sempre ressurgir do esgotamento de sua vitória ou derrota e reviver num novo confronto festivo no ano vindouro. O Boi emblema do grupo de brincantes é simbolizado em miniaturas, desenhos e muitas imagens estampadas em camisetas, nas paredes das casas e em bandeirolas espalhadas pela cidade. Do ponto de vista afetivo, entretanto, o Boi mítico parece se concretizar sobretudo no boi-artefato dançante para onde convergem, quando em ação ritual, os sentimentos de apreço profundo e de carinho devotados pelos brincantes a seu Boi.

Nos ensaios e nas performances festivas, nas saídas de rua, nas comemorações de vitória ou de derrota, o comparecimento do Boi dançante é sempre cercado de especial atenção e emoção. Nas performances na arena nas noites da festa, sua principal ação ritual é uma exímia dança. Essa dança, a um só tempo vigorosa, ágil e graciosa, é executada graças ao talento do tripa - o bailarino que se enfia dentro da carcaça do bicho inteiramente adaptada a seu corpo. Em Parintins, esse boi-artefato bailante ganha o mesmo nome do grupo de brincantes, ele encarna o Boi Caprichoso ou o Boi Garantido, é o símbolo máximo da agremiação. O Boi Caprichoso sendo representado com o corpo preto e uma estrela azul na testa, o Boi Garantido, com o corpo branco e um coração vermelho na testa.

Em Parintins, porém, o núcleo semântico associado às narrativas da morte e da ressurreição do Boi ampliou-se e deslocou-se, incorporando o ambiente amazônico e a cultura cabocla com suas lendas e criaturas sobrenaturais, as diferentes culturas indígenas regionais, as muitas histórias de destruição de grupos antigos e a defesa ecológica da mata. De tal modo que as

19 Remeto o leitor interessado nos detalhes da etnografia e história da festa a Cavalcanti, 2000. Para a análise da produção ritual da rivalidade, ver Cavalcanti, 2018. 
apresentações anuais ganharam um slogan, um tema-título, derivado desse universo simbólico regional mais amplo. Nas três noites da festa, Boi Caprichoso (o boi preto com uma estrela azul na testa) e Boi Garantido (o boi branco com um coração vermelho na testa), cada qual com cerca de 3.500 brincantes, revezam-se na arena do Bumbódromo em espetáculos de cerca de duas horas e meia de duração. A limitação da competição a dois contendores é contrabalançada pela grande elaboração interna da performance. A cada noite, mantendo um mesmo modelo de apresentação, os grupos renovam suas fantasias, carros alegóricos e lendas.

Atualmente, cada noite da performance de cada grupo se organiza em torno de 3 grandes cenários alegóricos, cuja atuação, se nela incluirmos sua montagem e desmontagem, dura cada uma cerca de 45 minutos. Esses cenários funcionam como molduras vivas para as diferentes sequências dramáticas que nelas se desenrolam, trazendo as danças das tribos e os principais personagens do grupo do Boi. Em cada sequência sucedem-se eventos que conduzem a um clímax final. A boa apresentação, pontuada por apogeus, digamos, de intensidade média, desenvolve-se em direção a uma apoteose dramática alcançada geralmente na sequência alegórica final, denominada "Ritual". Tudo então se esvai, para recomeçar nas noites seguintes.

Por vezes, uma dessas sequências traz a história dita da origem da brincadeira. Ela integra, de modo bastante livre, o que os dois grupos chamam de "Celebração Folclórica" (Garantido) ou "Exaltação folclórica" (Caprichoso), em que se encena de modo alusivo o suposto auto "trazido pelos nordestinos". Não interessa que o dono de um dos bois locais, o Garantido, de origem mais popular, tivesse origem cabo-verdiana. Não importa também que um pesquisador do calibre do paraense Vicente Salles tenha encontrado registros do Bumba Meu Boi em Óbidos, no Pará, em 1819 (SALLES, 1970). Nem mesmo que Avé-Lállemant (1961) tenha descrito um Bumbá nas ruas de Manaus em 1859, bem antes, portanto, da imigração nordestina motivada pelo ciclo amazônico da borracha. Não importa também que Câmara Cascudo (1984) tenha estabelecido o Norte e o Nordeste como as regiões onde o Bumba Meu Boi teria surgido simultaneamente no país com sua originalidade dançante. Nem que o próprio Mário de Andrade tenha comentado nas DD como os Reisados, em rápido desaparecimento no Nordeste, persistiriam ainda "com muita vida na Amazônia, representados pelo tempo do São João" (ANDRADE, op. cit. p. 40). O Bumba Meu Boi do Nordeste, onde supostamente se encena o auto do boi, é visto como a fonte da autenticidade cultural com a qual os Bumbás de Parintins se ligam imaginariamente, reivindicando sua expressão ímpar, pós-moderna e espetacular como integrante do "folclore tradicional".

Do meu material de pesquisa extraio algumas dessas celebrações do suposto folclore tradicional. Nos roteiros das 3 noites do Bumbá Garantido, apresentados aos jurados em 2003, vemos as seguintes definições:

Primeira Noite. Celebração Folclórica (Noite Cabocla) - A batucada vai para o proscênio. Israel Paulain [o Apresentador] chama todos para a Celebração Folclórica que começa a ser montada. 
A Estrutura artística tem ao centro a imagem do poeta Thiago de Melo. Ele está em um ambiente que recria seu universo poético. A Alegoria do artista Marialvo Brandão traz os personagens Amo do Boi, Sinhazinha da Fazenda, o Boi Garantido, Pai Francisco e Mãe Catirina, o Bailado Corrido e a Vaqueirada, que compõem o auto do boi.

Segunda Noite. Celebração Folclórica (Noite Folclórica) - A batucada ocupa o proscênio, enquanto o Apresentador Israel Paulain convida a todos para brincar de boi com a Celebração Folclórica que começa a ser montada. A estrutura artística tem em seu centro um gigantesco coração, cercado de querubins da tradição, uma referência aos elementos religiosos que originaram a promessa de mestre Lindolfo Monte Verde, o criador do Boi Garantido, o boi de promessa. Nessa alegoria, obra de Mestre Jair Mendes, virão os personagens Amo do Boi, Sinhazinha da Fazenda, o Boi Garantido, Pai Francisco e Mãe Catirina, o Bailado Corrido e a Vaqueirada, que compõem o auto do boi.

Terceira Noite. Celebração Folclórica (Santuário Esmeralda) - Quando a tribo Tupinambá deixa o centro da arena, entra a estrutura artística Celebração Folclórica do Boi, Florais da Amazônia (do artista Vandir Santos), que traz os personagens do auto, Amo do Boi, Sinhazinha da Fazenda, Pai Francisco, Catirina, Bailado Corrido e a Vaqueirada. Eles bailam ao som da toada Nona Evolução, de Tadeu Garcia. O final da Celebração Folclórica é a deixa para que as Tribos tomem conta da arena e executem uma grande coreografia em celebração a todas as nações indígenas".

O Boi Caprichoso, por sua vez, assim descreve a sequência dramática Exaltação Folclórica, apresentada na primeira noite de 2010, que tinha como slogan "Poesia Cabocla, um canto de amor ao folclore popular": "Na Exaltação Folclórica desta noite, o Boi Caprichoso reverencia por meio da toada a cultura, suas raízes e tradições exaltando figuras do mais puro folclore parintinense que ganham vida e transformam o cenário em um palco de celebração e tradição com personagens como o Lamparineiro "Lioca”, o Marujeiro "Chumbão", o Vaqueiro "Jacaré" (in memorian) e a Marujeira Chica, que desde criança brincaram de boi emprestando seu brilho de gente simples do povo e simbolizando a homenagem do Boi Caprichoso. A Exaltação privilegia os itens do auto do boi, Pai Francisco e Mãe Catirina, Marujada, Vaqueirada, Lamparineiros, Bailado Tradicional, Sinhazinha da Fazenda, Amo e o símbolo maior da nossa festa, o Boi Caprichoso. Dona Aurora, Gigante, os compadres Gazumbá e Mãe Guiomá, fonte viva do folclore popular, completam o mosaico folclórico e cultural do Boi de Parintins. Essa manifestação folclórica emana da alma do caboclo e se eleva ao mundo através dos versos e estrofes das toadas como uma mensagem de apelo e conscientização, expressando o mais puro sentimento do povo amazônida". (Caprichoso. O canto da Floresta. Roteiro de Apresentação, 2010, p. 48-49).

Nas sequências dramáticas mencionadas, e em seus congêneres que se repetem anualmente, celebra-se o "folclore tradicional", e nelas se concentra a atuação dos elementos e personagens 
ligados às narrativas de origem do Bumba Meu Boi. Essas sequências definem também um núcleo cênico que se associa geralmente à própria chegada do boi-artefato-dançante na arena. Embora sua atuação conjunta se concentre nesses momentos, esses personagens - o próprio boi, seu amo, sinhazinha da Fazenda, Pai Francisco e Mãe Catirina, vaqueirada -, entretanto, se espraiam por todo o espetáculo em Parintins e o entremeiam de modo muito variado.

Símbolo da agremiação e motivo central de todo o espetáculo, o surgimento do boiartefato-dançante é sempre uma "surpresa"; o boizinho pode sair misteriosa e inesperadamente de uma alegoria em forma de coração vermelho, que gira e explode fogos de artifício com sua chegada. Ou da boca, subitamente aberta, de um assustador monstro Mapinguari. Pode vir do céu, pendurado numa estrela, ou sair de dentro de um disco voador. Pode emergir alegre e simplesmente no seio da entusiasmada galera que torce por ele nas arquibancadas. Ou pode surgir ainda de dentro de um círculo de fogo, da mão gigantesca do Criador, ou das profundezas de um rio... Sua chegada é sempre saudada com muitos fogos de artifício e toada especial. Antes dele, já chegou seu Amo, chamando-o com o berrante para brincar na arena e entoando uma toada de improviso e desafio ao Amo do Boi contrário (que, interpelado, responderá agressiva e jocosamente na apresentação do contrário que se sucede). Vem também a vaqueirada - cerca de 40 componentes caracterizados de vaqueiros, enfiados no saiote que simula um cavalo que executa em volta do boi uma coreografia especial. E há sempre a entrada em cena de Pai Francisco e Mãe Catirina, personagens que, como as Baianas nas escolas de samba carioca, são itens obrigatórios, embora não sejam itens de julgamento. Eles chegam geralmente vestidos de palhaços, pintados de negro, saltitando, pulando e caindo pela arena.

Depois de sua chegada, o boi executa uma dança solo ao som da toada que o celebra. Com ele em cena, lá vem também a Sinhazinha da fazenda, que também faz uma apresentação individual - um bailado delicado, leve e gracioso, de dócil sensualidade - ao som de toada especial. Ela é "a filha mais querida do dono da fazenda" e seria como que a "anfitriã da festa no terreiro da fazenda". O figurino de Sinhazinha é sempre um luxuoso vestido rodado, chapéu e sombrinha ${ }^{20}$. Antes de despedir-se da galera ou retirar-se para um dos lados da arena, cedendo o centro da cena para outros personagens do espetáculo, o boi deve também comer capim e sal dado pela Sinhazinha da Fazenda. Geralmente ausente das outras sequências dramáticas, ele voltará ao final do espetáculo para conduzir o grupo brincante para fora da arena. Seu "tripa" - aquele que dança nas entranhas do boi - é sempre um exímio bailarino que movimenta com leveza e graça a carcaça do bicho sob a qual dança escondido ${ }^{21}$.

20 É tentador contrastar o balé da Sinhazinha com outra personagem feminina, geralmente parceira do Pajé, a Cunhã Poranga (a moça mais bonita em língua tupi) em sua dança e fantasia sensuais. Há ainda a porta-estandarte, que defende dançando o emblema da agremiação e a rainha do folclore, quase uma duplicação, menos ousada, no entanto, da Cunhã.

21 No Boi Caprichoso, o "tripa” é também o artista que confecciona a armação do boi. Esta deve estar perfeitamente adaptada a seu corpo, permitindo o movimento mais livre possível, e assegurando a graça desse bailado de mímica, que exige a habilidosa manipulação da armação (o boi fica ereto, ou se curva, mexe a cabeça para ambos os lados) e o acionamento dos mecanismos para os efeitos especiais: o coração ou a estrela da testa brilham ou pulsam; 
Esse conjunto de personagens dança também coletivamente e encena de modo solto e alusivo à "história da origem" do "auto do boi", enquanto a alegoria central da sequência dramática que homenageia o folclore "da origem" acontece no centro da arena ${ }^{22}$.

Outras sequências dramáticas, encenadas a cada noite de performance, disputam, entretanto, a atenção do expectador e o empenho dos brincantes. Desde os anos 1980, o Bumbá de Parintins acolheu decididamente os inúmeros temas míticos regionais e amazônicos que conferiram à festa sua tonalidade ímpar. As mortes e ressurreições direta e efetivamente exaltadas e encenadas na arena não são as do boi, mas aquelas apresentadas nas sequências dramáticas que elaboram mitos indígenas ou ribeirinhos da região amazônica. Há, em especial a sequência autodenominada "Ritual", o ponto alto de cada performance festiva, que traz como personagem principal não o boi-artefato-dançante, mas o Pajé, ele também um exímio bailarino. O clímax festivo alcançado nesse momento revela o deslocamento do tema da morte e da ressurreição para a mitologia de fundo indígena. Entre os anos 1990 e 2000, quando a fama do Bumbá expandiu-se nacional e internacionalmente, tal deslocamento levou-me a interpretar essa festa (CAVALCANTI, 2000) como a expressão de um novo indianismo, emblemático da abertura do Bumbá para o ambiente amazônico e de sua participação no desejo de construção de uma identidade cultural regional renovada.

\section{Conclusão}

A história da morte e ressurreição do boi precioso, estabelecida entre nós como sendo aquela "da origem" do folguedo do Bumba Meu Boi, demonstra certamente grande poder de mitização 23. Quando simplificada na bibliografia dos estudos de folclore pela ideia de um auto, ou mesmo se, seguindo Mário de Andrade, procurarmos com ela o tal "entrecho dramático" bem definido que conteria a unidade estética e intelectual da performance, somos levados inevitavelmente a corroborar a ideia da perda inexorável das tradições populares e de sua corrupção por valores tidos como mais modernos. Por mais pujante que se apresente a nossos olhos uma expressão festiva, do ponto de vista de um "conteúdo fixo nacionalizante", almejado pelo projeto cultural e ideológico de Mário de Andrade, vence a visão pessimista com relação às tradições populares, em um tipo de discurso já bem denominado por Gonçalves (2003) como "retórica da perda".

Há, porém, um outro tipo de elo entre as formulações de Mário de Andrade relativas ao Bumba Meu Boi, que tanto influíram nos estudos de folclore que se sucederam, e a atualidade do Bumbá de Parintins. O elo criativo entre esses dois tempos do Boi pode ser encontrado na percuciente resenha já mencionada de Merquior (1981) ao livro de Mello e Souza (1979).

sai fumaça por suas narinas. A cada ano, o boizinho traz também suas surpresas.

22 Sobre a forma de significação das alegorias no Bumbá, ver Cavalcanti 2011 e 2015.

23 Mitismo ou mitização é um conceito elaborado por Marcel Détienne (1992) referente à capacidade de certas histórias de se tornarem mitos na vida coletiva. 
Ao comentar a visão trágica e ambivalente que perpassa o romance Macunaíma (ANDRADE, 1988), Merquior chamou nossa atenção para a presença de um otimismo da forma em Mário de Andrade. Seu texto ilumina outro aspecto fundamental da interpretação de Mello e Souza que vale ressaltar: a importância da forma estética na solução da busca nacionalista de nosso autor ${ }^{24}$. Haveria aqui, um "otimismo da forma" expresso no compartilhamento do modelo compositivo entre as formas europeias da suíte e da variação, da música e dança populares, do romance Macunaíma. A positividade nacionalista do projeto de Mário de Andrade - "nacionalismo de modulação", de qualidade estética "excepcionalmente inclusiva” (Idem, p. 266) - repousaria, então, não na leitura ufanista do conteúdo do romance, de um pessimismo próximo ao trágico, mas na solução formal da expressão artística.

Mário de Andrade trabalhou a apresentação do tema central ao folguedo exposto no entrecho dramático com a noção antropológica de mito evolucionista, vigente na obra dos autores a que recorreu na época ${ }^{25}$. É possível, entretanto, trabalhar a ideia de um motivo central ao Boi (mesmo que tal motivo não seja dramatizado em sentido estrito no folguedo), a partir da noção estruturalista de mito elaborada em especial por Claude Lévi-Strauss (1967, 1993), libertando assim o Bumbá da ideia da encenação de um "roteiro". Quando o fiz em análise anterior (CAVALCANTI, 2006), o motivo da morte e ressurreição do boi emergiu de fato como uma potente matriz de sentido a alimentar um vasto processo de fabulação mítica ainda vivo, atualizado e ressignificado a cada ano nas narrativas e nas performances festivas dos Bumbas e Bumbás país afora.

Porém, além disso, o registro mais fragmentário de apreensão das danças dramáticas, também proposto por Mário de Andrade, parece emergir como particularmente pertinente para a compreensão do Bumbá de Parintins. O arcabouço estético e performático dos espetáculos contemporâneos do Bumbá de Parintins ilumina-se quando enfocado pelo viés de leitura das DD, o qual enfatiza a dimensão artística e a natureza de performance das expressões populares. Peço licença a Mário de Andrade e permito-me acrescentar dois ajustes significativos a sua formulação, trazidos pela contemporaneidade e dinâmica dos processos culturais populares: o primeiro é de natureza dramático-visual e abre lugar para a relevância dos grandiosos cenários alegóricos nas apresentações dos Bumbás; e o segundo, de natureza semântica, abre espaço para o decidido deslocamento do tema da morte e da ressurreição do boi amazônico rumo à mitologia indígena e ribeirinha. Torna-se então altamente esclarecedor definir sumariamente o Bumbá de Parintins como uma sequência dançada e cantada de cenas dramáticas que, apresentadas em espetaculares cenários alegóricos, articulam-se livre e fragmentariamente em torno de um conjunto de personagens alusivos ao motivo da morte e ressurreição de um boi mítico, o qual se

24 Esse mesmo ponto, por sinal, é a base do argumento de Moraes (1999).

25 As principais referências teóricas para a noção de mito com que Mário de Andrade trabalhava são as obras de Frazer, Tylor e Lévy-Bruhl. 
deslocou em Parintins rumo ao imaginário mitológico indígena e caboclo. Isso feito, podemos então começar a compreendê-lo em sua originalidade.

\section{Referências}

ANDRADE, Mário de. Macunaíma. Coleção Arquivos. Paris/Brasília: UNESCO/CNPq, 1988. . As danças dramáticas do Brasil. In: ALVARENGA, Oneida (Org.). Danças dramáticas do Brasil. São Paulo: Itatiaia/ Instituto Nacional do Livro/ Fundação Pró-Memória, 1982. p. 23-84.

O turista Aprendiz. Estabelecimento do texto, introdução e notas de Telê Porto Ancona Lopez. São Paulo: Livraria Duas Cidades/ Secretaria da Cultura, Ciência e Tecnologia, 1976.

. Música de feitiçaria no Brasil. Belo Horizonte: Ed. Itatiaia, 1983.

The Music of sorcery in Brazil. Tradução de Peter Fry. Vibrant, Virtual Brazilian Anthropology, Brasília, v.14, n.1, p. 1-24, jul. 2017.

AVÉ-LALLEMANT, Robert. Viagem pelo Norte do Brasil no ano de 1859. Rio de Janeiro: Instituto Nacional do Livro, Ministério da Educação e Cultura, 1961.

AZEVEDO, Artur. O bumba meu boi. Revista Kosmos, v. 2, n. 9, p. 9-14, 1906.

BORBA FILHO, Hermilo. Apresentação do bumba meu boi. O boi misterioso de Afogados. Recife: Imprensa Universitária, 1966.

BORDALLO DA SILVA, Armando. Contribuição ao estudo do Folclore Amazônico na Zona Bragantina. Bragança: Funarte / Fundação Cultural de Bragança, 1981.

CÂMARA CASCUDO, Luiz da. Dicionário de Folclore Brasileiro. Belo Horizonte: Itatiaia, 1984.

CARVALHO, Luciana Gonçalves. A graça de contar: um Pai Francisco no bumba meu boi do Maranhão. Rio de Janeiro: Aeroplano Editora, 2011.

CAVALCANTI, Maria Laura Viveiros de Castro. O Boi Bumbá de Parintins: breve história e etnografia da festa. Revista História Ciências e Saúde - Manguinhos, Rio de Janeiro, v. 6, p. 1019-1046, set. 2000.

O Indianismo revisitado pelo Boi Bumbá. Notas de pesquisa. Somanlu. Revista de Estudos Amazônicos, Manaus, Valer Editora / Universidade do Amazonas, v. 2, n. 2, p. 127-135, 2002.

Tema e variantes do mito: sobre a morte e a ressurreição do boi. Mana. Estudos de Antropologia Social, Rio de Janeiro, v. 12, n. 1, p. 69-104, abr. 2006.

Alegorias em ação. Sociologia \& Antropologia, Rio de Janeiro, v. 1, n. 1. jun. 2011. p. 233-249.

Reconhecimentos. Antropologia, folclore e cultura popular. Rio de Janeiro: Aeroplano Editora, 2012a.

Cultura popular e sensibilidade romântica. As danças dramáticas de Mário de Andrade. In: CAVALCANTI,

ML. (Org.). Reconhecimentos. Antropologia, folclore e cultura popular. Rio de Janeiro: Aeroplano Editora, 2012b. p. 288-347.

.Tempo e Narrativa nos folguedos do boi. In: CAVALCANTI, ML. (Org.). Reconhecimentos. Antropologia, folclore e cultura popular. Rio de Janeiro: Aeroplano Editora, 2012c. p. 351-381.

Os sentidos no espetáculo. In: CAVALCANTI, ML. (Org.). Carnaval, ritual e arte. Rio de Janeiro: Ed. 7Letras, 2015. p. 35-65.

O ritual e a brincadeira: rivalidade e afeição no Bumbá de Parintins, Amazonas. Mana. Estudos de Antropologia Social, Rio de Janeiro, v. 24, n. 1, p. 009-038, 2018.

.; FRY, Peter. Brazil's music of sorcery according to Mário de Andrade: an introduction by the editors. Vibrant, Virtual Brazilian Anthropoly, Rio de Janeiro, v. 14, n. 1, p. 1-6, 2017. 
DAMATTA, Roberto. Digressão: a fábula das três raças, ou o problema do racismo à brasileira. In: Relativizando: uma introdução à antropologia social. Rio de Janeiro: Ed. Rocco, 1987. p. 58-85.

DÉTIENNE, Marcel. A invenção da mitologia. Brasília/Rio de Janeiro: Ed. UnB/José Olympio Editora, 1992.

FERREIRA, Ascenso. O bumba meu boi. Revista Arquivos. Recife: Prefeitura Municipal do Recife, n. 1-2, 1944, p. 121-157.

GONÇALVES, José Reginaldo. A retórica da perda: discurso nacionalista e patrimônio cultural no Brasil. Rio de Janeiro: Ed. UFRJ, 2003.

GONÇALVES, Renata. A dança nobre do Carnaval. Rio de Janeiro: Ed. Aeroplano, 2010.

HOBSBAWN, Eric. Introdução: a invenção das tradições. In: HOBSBAWN, Eric; RANGER, Terence. (Orgs.) A invenção das tradições. Rio de Janeiro: Paz e Terra, 2006. p. 9-24.

A produção em massa de tradições: Europa, 1879 a 1914. In: HOBSBAWN, Eric; RANGER, Terence (Orgs.). A invenção das tradições. Rio de Janeiro: Paz e Terra, 2006. p. 271-316

LÉVI-STRAUSS, Claude. O pensamento Selvagem. São Paulo: Ed. Nacional. 1976.

Antropologia Estrutural. Rio de Janeiro: Tempo Brasileiro, 1967.

Antropologia Estrutural 2. Rio de Janeiro: Tempo Brasileiro, 1993.

LOPES GAMA., Miguel do Sacramento. A estultice do Bumba-meu-boi. In: MELLO, Evaldo Cabral de. (Org.). O carapuceiro. São Paulo: Companhia das Letras, 1996. p. 330-38.

LOPEZ, Telê Porto Ancona. Mário de Andrade: ramais e caminhos. São Paulo: Duas Cidades, 1972.

O boi em Mário de Andrade. In: MOITARÁ, SOCIEDADE BRASILEIRA DE PSICOLOGIA ANALÍTICA, 16, São Paulo/Campos de Jordão. Anais do Moitará, Sociedade Brasileira de Psicologia Analítica, Campos do Jordão 2002. p. 6-13. (mimeo).

MARTINS, Marcelo Adriano. Duas trajetórias, um modernismo musical? Mário de Andrade e Renato Almeida. 2009. 131 f. Dissertação (Mestrado em Sociologia e Antropologia) - Programa de Pós-Graduação em Sociologia e Antropologia, Instituto de Filosofia e Ciências Sociais, Universidade Federal do Rio de Janeiro, Rio de Janeiro131p. MELLO E SOUZA, Gilda. O tupi e o alaúde. São Paulo: Duas Cidades, 1979.

MERQUIOR, José Guilherme. Macunaíma sem ufanismo. In: (Org.). As ideias e as formas. Rio de Janeiro: Nova Fronteira, 1981. p. 264-269.

MEYER, Marlyse. O elemento fantástico numa forma de teatro popular brasileiro. In: (Org.). Pirineus, caiçaras. Campinas: Ed. Unicamp, 1991. p. 55-70.

MORAES, Eduardo Jardim de. A brasilidade modernista: sua dimensão filosófica. Rio de Janeiro: Graal, 1978. .Modernismo e folclore. In: SEMINÁRIO FOLCLORE E CULTURA POPULAR: AS VÁRIAS FACES DE UM DEBATE, Rio de Janeiro. Série Encontros e Estudos. Rio de Janeiro: CNFCP/Funnarte, 1992. p. 75-78.

. Limites do moderno: o pensamento estético de Mário de Andrade. Rio de Janeiro: Relume do Mará, 1999. PEREIRA DE QUEIROZ, Maria Isaura. O bumba meu boi, manifestação de teatro popular no Brasil. Revista do Instituto de Estudos Brasileiros, São Paulo, v. 1, n. 2, 1967, p. 87-97.

SAHLINS, Marshall. Adeus aos tristes tropos: a etnografia no contexto da moderna história mundial. In:

Cultura na prática. Rio de Janeiro: EdUFRJ, 2004. p. 503-543.

SALLES, Vicente. O boi-bumbá no ciclo junino. Brasil Açucareiro, Rio de Janeiro, n. 38, p. 27-33, 1970.

SOARES, Lélia Gontinjo. (Org.). Mário de Andrade e a Sociedade de Etnografia e Folclore: 1936-1939. Rio de Janeiro: FUNARTE/Secretaria Municipal de São Paulo, 1983.

TRAVASSOS, Elizabeth. Um colóquio de bruxos: Mário de Andrade, Fernando Ortiz e a "música de feitiçaria".

Debates, Rio de Janeiro, n. 12, p. 13-23, jun. 2014.

TYLOR, Edward B. Primitive Culture ( 2 vols.). London: 1871. 
VALENTINI, Luisa. Um laboratório de Antropologia. O encontro entre Mário de Andrade, Dina Dreyfus e Claude Lévi-Strauss (1935-1938). São Paulo: Ed. Alameda, 2013.

VILHENA, Luiz Rodolfo da Paixão. Projeto e missão: o Movimento Folclórico Brasileiro (1947-1964). Rio de Janeiro: Fundação Getúlio Vargas/ Funarte, 1997

Recebido em: 15/07/2018

Aceito em: 15/10/2018 